\title{
The Image of Marshal Mannerheim, Moral Panic, and the Refashioning of the Nation in the 1990s
}

Tuomas Tepora

\section{INTRODUCTION}

The end of the Cold War resulted in radical changes in Finland's international position and economy. It sparked an identity struggle, seen within society as soul-searching. One of the major national symbolic figures, Marshal Carl Gustaf Emil Mannerheim (1867-1951), the Civil War (1918) and World War II military leader and the President of Finland (1944-1946), became a mirror in this collective introspection. This chapter addresses the personality cult surrounding Marshal Mannerheim, as well as the alternating images of him, as keys to understanding the emotional and social upheavals within Finnish society in the early 1990s.

The chapter focuses on the debate in the early 1990s concerning the construction of the Museum of Contemporary Art next to the Mannerheim

\footnotetext{
T. Tepora $(\bowtie)$

University of Helsinki, Helsinki, Finland e-mail: tuomas.tepora@helsinki.fi

(C) The Author(s) 2021

V. Kivimäki et al. (eds.), Lived Nation as the History of Experiences and Emotions in Finland, 1800-2000, Palgrave Studies in the History of Experience, https://doi.org/10.1007/978-3-030-69882-9_14
} 
equestrian statue at the heart of Helsinki. The debate offers invaluable insight into the emotional memory politics, the layers of memories, and future expectations in the post-Cold War nation. In the early 1990s, the Mannerheim statue and contemporary art formed an oxymoron that seemed to threaten the moral base of the nation. The juxtaposition symbolized a moral panic that concerned the lived experience of Finland's changing international position. Through the concept of "lived experience," I intend to show how individual citizens sought emotional advice from the perceived national collective. By "moral panic," I refer to a media-driven and emotionally charged debate that concerned the moral foundations as well as the future of society.

Trained and having served in the Imperial Russian Army until 1917, Mannerheim's dominant public image is as the Marshal of Finland, the celebrated Commander-in-Chief of the Finnish Army during World War II. Yet, since 1918, and up until World War II, his dominant image had been that of the White General of the victorious White Army in the Finnish Civil War. ${ }^{1}$ For many defeated socialists, however, he symbolized a demonic butcher-in-chief. Out of more than 36,000 people who perished as a consequence of the bloody civil war, more than three-fourths were socialists, known as the Reds. This bitter emotional legacy has significantly contributed to the Mannerheim cult, which derives its power from controversy. Mannerheim the butcher is a "conservative" figure. That figure resists change as strongly as its revered counterpart, Mannerheim the marshal. Thus, the most creative and productive building blocks for the Mannerheim personality cult are found between conservative poles. This is the territory of the playful and eroticized Mannerheim, the cosmopolitan and artloving aristocrat. This is also the territory of a plethora of commercial brands, which also utilize the conservative imagery. The Mannerheim image, as with any public image in open societies, has also been susceptible to decoding and recoding over time. The dominant Mannerheim figures may be seen as keyholes into significant cultural and social changes. ${ }^{2}$ One major turning point occurred at the end of the Cold War, as will be discussed in this chapter.

${ }^{1}$ J. E. O. Screen, Mannerheim: The Finnish Years (London: Hurst, 2000).

${ }^{2}$ Päivän Sanomat 31 January 1959; Yrjö Niiniluoto, Suuri rooli: Suomen marsalkan, vapaaherra Carl Gustaf Mannerheimin kirjallisen muotokuvan yritelmä (Helsinki: Otava, 1962); Tuomas Tepora, "Ratsastajapatsas, moraalinen paniikki ja nykytaide: Mannerheimmielikuvien muuttuvat merkitykset ja niiden rakentajat 1900-luvulla," in Yhteisöstä yksilöön: Juha Siltalan jublakirja, ed. by Marja Jalava, Ilkka Levä, Tuomas Tepora \& Ville Yliaska (Helsinki: Into, 2017). 


\section{Emotions, Remembrance, and a Nontotalitarian Personality Cult}

During Mannerheim's lifetime, and especially after his death, the Mannerheim image had developed into an emotional figure that could be understood as a symbol and a container of contradictory public emotions. ${ }^{3}$ Accordingly, "emotional figures" reflect, circulate, and amplify a wide range of social emotions expressed and commemorated in society. From the perspective of the history of emotions, the Mannerheim images can be seen as having been used in the expression and production of public and collectively shared or contested feelings. The Mannerheim personality cult may not have drawn huge crowds rallying around his few statues. Instead, the conservative Mannerheim cult and its strong counterimages marked off urban and rural spaces with memorials and with emotional memories that both supported and challenged the intended meanings. These emotional figures created certain emotional spaces and demarcation lines, such as the statue sites, certain buildings such as his former Headquarters in Mikkeli or symbolically highly charged defensive structures, namely, the Mannerheim defensive line in Karelia. It thus warrants asking how the Mannerheim image worked (or works, for that matter) as an emotional figure?

Imagined, internalized emotional figures can, of course, be powerful. When one spotted a Mannerheim image, or read or heard mention of the name of the Marshal, it became difficult to remain ignorant. One was forced to have an opinion. Obviously, there was no single Mannerheim image but, rather, competing images that represented, reflected, and recoded new waves of Mannerheim "emotionology" and emotive, transformative manifestations. ${ }^{4}$ One wondered what and how to feel in connection with the values Mannerheim represented, and, most importantly, why one should be wary of not publicly trespassing the sacred boundary around his image. Smearing or defacing a Mannerheim statue was a political statement, but it was also a distinctly emotional statement unlike with any other statue of historical or political significance.

\footnotetext{
${ }^{3}$ For a corresponding concept in memory studies, "figures of memory," see Jan Assmann, "Collective Memory and Cultural Identity," New German Critique 65 (1995), 125-33.

${ }^{4}$ Peter N. Stearns \& Carol Z. Stearns, "Emotionology: Clarifying the History of Emotions and Emotional Standards," American Historical Review 90:4 (1985), 813-36; William M. Reddy, The Navigation of Feeling: A Framework for the History of Emotions (Cambridge: Cambridge University Press, 2001), 96-111; Rob Boddice, The History of Emotions (Manchester: Manchester University Press, 2018), 59-70.
} 
I understand the function of personality cults in democratic societies as the depositories of socially constructive emotions. Thus, they are points of negotiation, unity, and discord between social groups within the collective. I draw from the cross-fertilization of the history of emotions and memory studies. My key sources include the archival material of the Marshal Mannerheim Heritage Foundation (Suomen Marsalkka Mannerheimin perinnesä̈̈tiö, MHF) and the elite veteran's organization for the Knights of the Mannerheim Cross. These offer invaluable insight into conservative Mannerheim imagery and the methods of its guardians. Scholars have identified contemporary recreations and decoding of the Marshal as increasingly mediatized phenomena. The media along with social media form the sites for Mannerheim controversies, discussions, and "sacralization" 5 and offer insights into alternate Mannerheim images and emotional representations. The discussion here is complemented by an interview with history professor Matti Klinge, a member of the MHF board in the 1980s and early 1990s, prior to the statue and museum polemic.

Modern, political personality cults have traditionally been implemented in totalitarian societies. Historians and political scientists share a rather straightforward consensus that the construction and maintenance of personality cults serve instrumental goals. They mobilize and indoctrinate people and build political hierarchies around the leader. These structural layers of hierarchies within closed autocracy form the basis of a totalitarian society. ${ }^{6}$ Nontotalitarian personality cults, in turn, may have instrumental purposes, but the reception of the cultic figures is difficult, if not

\footnotetext{
${ }^{5}$ Tarja Väyrynen, "Keeping the Trauma of War Open in the Male Body: Resisting the Hegemonic Forms of Masculinity and National Identity in Visual Arts," Journal of Gender Studies 22:2 (2013), 137-51; Jere Kyyrö, "Sacredness as a Resource, Sacralization as a Strategy: Field Marshal Mannerheim and Finnish Fields of Media and Cultural Production," Implicit Religion 20:1 (2017), 43-64; Jere Kyyrö, Mannerheim ja muuttuvat tulkinnat: Mediatisoitunut kansalaisuskonto 2000-2010-lukujen kulttuurikiistoissa (Jyväskylä: Jyväskylän yliopisto, 2019).

${ }^{6}$ Robert C. Tucker, “The Rise of Stalin's Personality Cult," American Historical Review 84:2 (1979), 347-66; Ian Kershaw \& Moshe Lewin, Stalinism and Nazism: Dictatorships in Comparison (Cambridge: Cambridge University Press, 1997); Balázs Apor, Jan C. Behrends, Polly Jones \& E. A. Rees, eds, Leader Cults in Communist Dictatorships: Stalin and the Eastern Bloc (London: Macmillan, 2004); Jan Plamper \& Klaus Heller, eds, Personality Cults in Stalinism/ Personenkulte im Stalinismus (Göttingen: Vandenhoeck \& Ruprecht, 2004); Jan Plamper, The Stalin Cult: A Study in the Alchemy of Power (New Haven: Yale University Press, 2012).
} 
impossible, to control. As famously noted by Max Weber, modern, bureaucratic leadership relies on legal authority and rationality. This form of rule should be the most immune to personality cults, yet charismatic leaders have not been uncommon in modern Western societies. Weber, propounding his theory of authority before the era of twentieth-century totalitarianisms, was conceiving of a party leader. ${ }^{7}$

The twentieth century can be described as the era of the personality cult. In that period, different forms of totalitarian and authoritarian leadership evolved around the globe. They produced various types of cult images that reflected corresponding emotional regimes of fear, awe, and ecstasy. Importantly, the calls for charismatic leadership and cult images were not confined to totalitarian societies. The wars and crises of the first half of the twentieth century produced political and military leaders in authoritarian, democratic, and hybrid societies within Western and Eastern Europe. These leaders, such as Miklos Horthy of Hungary, Józef Piłsudski of Poland, or Gustaf Mannerheim, already became mythicized, revered, and hated figures during their lifetime. The political elites and the leaders themselves utilized their positions to construct and maintain myths that served their political purposes and legacies. ${ }^{8}$

Nontotalitarian personality cults have been the object of tentative research, but the field is still in a formative phase of development. Works on the myths and images of political figures such as Abraham Lincoln and Charles de Gaulle have indicated that scholars of nontotalitarian personality cults may benefit from concentrating particularly on the afterlife of the leader figures. It seems that nontotalitarian personality cults reach their peak and procreative qualities in the commemoration of their leaders. The continuity of the totalitarian regimes is threatened by or at least faces a major challenge at the death or removal of the leader. Democracies, in turn, begin to evaluate, celebrate, defame, and commemorate the past leader. The surviving political establishment may or may not safeguard the legacies of the leaders, but in an open society safeguarding will eventually prove impossible. The leaders are transformed into images that in time may become focal points of the popular culture, as in the cases of

${ }^{7}$ Max Weber, "Die drei reine Typen der legitimen Herrschaft," Preussische Jahrbücher 187:1 (1922), 1-12.

${ }^{8}$ Catherine Horel, L'amiral Horthy: Régent de Hongrie (Paris: Perrin 2014); Monika Świda, "The Historical Figures of the Republic in the Process of Reconstruction of the National Imagery: Sidónio Pais and Józef Piłsudski," Studia Litteraria Universitatis Iagellonicae Cracovensis 7:4 (2012), 153-67. 
Mannerheim, de Gaulle, and President Urho Kekkonen of Finland. ${ }^{9}$ The key difference between totalitarian and nontotalitarian personality cults lies in their capacity to regenerate and decode meanings. One can and does satirize Hitler and Stalin and their brethren. One cannot, however, adopt a hybrid attitude toward the cultic qualities of these characters. In Mannerheim's case, one can scorn the military attributes of his image while endorsing his cosmopolitanism.

\section{The Neo-Patriotic Decade}

It is clearly historically unsound to label entire decades as representative of certain historical eras. In Finland, the 1989 revolutions in Eastern Europe and the collapse of the Soviet Union acted as catalysts for renewed explicit conservative patriotism - seen from within this framework, the 1990s have been called the neo-patriotic decade. ${ }^{10}$ The term refers to the recreated celebration of nationalistic and often populist values, especially in connection with the remembrance of World War II. To be precise, it is perhaps more accurate to describe the early 1990s as the neo-patriotic era proper and to connect the bulk of the latter part of the 1990s with the EuropeanUnion-friendly economic boom of the turn of the millennium.

In the early 1990s, the Eastern superpower had lost the Cold War and suddenly many Finns experienced the feeling that they not only had sided openly with the Western victors of the Cold War but were the moral victors of World War II. That is, defeated Finland reversed the consequences of the war. This change in ideas becomes understandable in light of the conservative version of Finnish war experience that had endured since the end of World War II, even if in a minor key. According to that view, the Finnish participation in the war had actually been an isolated and separate conflict from the war waged between the Allied and Axis powers.

Fluidly moving and self-contained, patriotic sentiments created unexpected combinations and results when they came into contact with other new and emotionally heavy currents within society, such as the question of

\footnotetext{
${ }^{9}$ Sudhir Hazareesingh, In the Shadow of the General: Modern France and the Myth of de Gaulle (Oxford: Oxford University Press, 2012), 144-69; Tuuli Lähdesmäki, "From Personality Cult Figure to Camp Image - the Case of President Urho Kekkonen," Participations 6:1 (2009).

${ }^{10}$ Tiina Kinnunen \& Markku Jokisipilä, "The Shifting Images of 'Our Wars': Finnish Memory Culture of World War II," in Finland in World War II: History, Memory, Interpretations, ed. by Tiina Kinnunen \& Ville Kivimäki (Leiden: Brill, 2012).
} 
joining the European Union or the consequences of the collapse of the bipolar globe. The neo-patriotic experience and public discourses became closely linked with a morally supportive atmosphere that found fuel and guidance from remembering the heroism shown 50 years before. The popularity of and the demand for realistic and patriotic rather than allegoric war films became one of the manifestations of the changed atmosphere of the 1990s. ${ }^{11}$

The war generation had by now reached the age of retirement and the conservative leaders of the veterans' movement took their positions as the guardians of the prescribed legacy of the war generation. In the guise of Director of the Board of the MHF, General Adolf Ehrnrooth, Mannerheim rose from the dead in order to finish the remaining worldly battle of the veterans. The General, in his late eighties, thus became a highly visible symbol of the veterans' generation and of renewed patriotism. Clearly the veterans included people from all walks of life, but in the media the "veterans" became synonymous with conservative neo-patriotism. It is also important to understand that the youth of the 1990s, in particular, adopted a nationalistic attitude. The social changes of the decade formed their key experience while the Finnish experience of World War II formed a unifying and predominantly positive historical point of reference. It provided a representation of a nationally uplifting and defensive battle. The veterans' generation found its closest ally from among teenagers and young adults in their early twenties. ${ }^{12}$

However, the young and the patriotic did not necessarily see joining the EU as problematic. This illustrates how the identities found themselves in the middle of the process of reorganization. In the United States, Francis Fukuyama famously anticipated the end of history, meaning the global victory of liberal democracy. Nationalism was considered to be an idea of the past, and national feeling, that is nationalism as an emotional phenomenon, seemed to be on its way to becoming a "lost emotion." The experience in the former socialist republics of Eastern Europe would soon prove otherwise. In Finland, many writers published works that defined

\footnotetext{
${ }^{11}$ Ville Yliaska, "Kansakunnan uudelleensynty,” in Yhteisöstä yksilöön: Juha Siltalan jublakirja, ed. by Marja Jalava, Ilkka Levä, Tuomas Tepora \& Ville Yliaska (Helsinki: Into, 2017), 326-36.

${ }^{12}$ Sirkka Ahonen, Historiaton sukupolvi? Historian vastaanotto ja historiallisen identiteetin rakentuminen 1990-luvun nuorison keskuudessa (Helsinki: Suomen Historiallinen Seura, 1998), 74-89, 120-3, 171-2; Pilvi Torsti, Suomalaiset ja historia (Helsinki: Gaudeamus, 2012), 135-55.
} 
"Finland" and sought new ways to prosper as a nation. The parochial celebrations of Finnishness, together with its peculiar national characteristics, became linked with a constant media struggle aimed at proving one's European-ness. The Finnish way of self-Europeanization was called, and perhaps then also experienced, as a form of "self-racism." 13

The Western recession of the early-1990s hit the Finnish economy exceptionally hard. Carefree private spending in the late 1980s resulted in a debt crisis furthered by the abrupt loss of the lucrative bilateral Soviet trade. The unemployment rate rose to a high of nearly 20 percent in 1994. ${ }^{14}$ The neo-patriotic turn cannot be understood without considering the concurrent relative economic misery, with many a lost job, business, piece of property, or dream. The widespread unemployment and the conservative celebration of Finnish moral superiority may seem contradictory to each other, but, as this chapter suggests, recession and essentially populist neo-patriotism became closely linked. This link was enhanced by the concurrent public debates and campaigns for and against joining the EU. Campaigners against joining the Union reflected the sentiment of not wishing to concede the country's newly acquired and reinvigorated independence to Brussels. In the October 1994 referendum, 43 percent of voters opposed joining. By 1994, the economy had started to recover, despite the fact that unemployment hit record levels. Everyday life was still filled with short-sightedness.

This experience coincided with perhaps the fiercest postwar battle connected with the significance of the remembrance of Marshal Mannerheim. The media spectacle of the year 1994 was the controversy surrounding the construction of the Museum of Contemporary Art at the heart of Helsinki, a spot occupied by the Mannerheim equestrian statue. Whereas in the late 1980s Mannerheim enthusiasts had lamented the media's lack of interest in the commemoration of the military leader, ${ }^{15}$ in the new geopolitical situation the entire emotional regime of the society seemed to lean toward embracing conservative symbolism.

\footnotetext{
${ }^{13}$ Satu Apo, "Suomalaisuuden stigmatisoinnin traditio," in Elävänä Euroopassa: Muuttuva suomalainen identiteetti, ed. by Pertti Alasuutari \& Petri Ruuska (Tampere: Vastapaino, 1998), 86.

${ }^{14}$ Findicator, Unemployment rate 1989 M01-2020 M02, https://findikaattori.fi/en/ table/34, accessed 15 April 2020.

${ }^{15}$ Mannerheim Heritage Foundation Archives (MHF), Folder Hb 1: Minutes of the Board (1980-2000), Minutes of the Board Meeting 28 January 1987.
} 


\section{The Statue and Contemporary ArT}

The Mannerheim statue in central Helsinki was unveiled on Mannerheim's birthday in 1960, after a decades-long process that had initially begun in the interwar period. After World War II, a popular movement instigated by the student body of the University of Helsinki and led by a board of professors, high-ranking military personnel, conservative politicians, and financial elites, finished the project in an impressive manner, mainly with donations from citizens. More than 600,000 people donated funds for the statue project in the 1950s. It is notable that the equestrian form of the statue connected it with symbolism of ancien régime sovereigns. Other than the equestrian Mannerheim statue in Lahti, unveiled in 1959, the Helsinki statue was the first of its kind in Finland. The Helsinki statue was designed by Aimo Tukiainen, who had previously finished commissioned works on military graves and, interestingly, Red civil war memorials. ${ }^{16}$ The Mannerheim Heritage Foundation was established in 1973 to continue the work of the statue committee. Its prime mover from the start was General Ehrnrooth, a relative of Mannerheim. ${ }^{17}$

The statue and its location have since formed a key site of memory in Finnish society. After a lengthy debate and extensive public planning, the site selected for the statue was at a major central crossroads on the main thoroughfare that in 1942 had been named Mannerbeimintie(Mannerheim Road), in the busiest and most visible spot of the city. The Parliament and the National Museum were situated nearby. The location was also the point at which Mannerheim had entered the city in May 1918 during the victory parade that symbolically ended the Civil War with a White victory. Although the statue otherwise depicted Mannerheim as a World War II Marshal, the controversial and divisive symbolism arising from the bitter legacy of Finland's brutal domestic war thus became interwoven with the symbolism of the statue's location. ${ }^{18}$ In spite of that prominent location, the proximity of the railway station meant that facing north-east from the

\footnotetext{
${ }^{16}$ Riitta Konttinen, Suomen Marsalkan ratsastajapatsas (Helsinki: Suomen Marsalkka Mannerheimin perinnesäätiö, 1989), 191-2, 194-5.

${ }^{17}$ Vera von Fersen, Ratsastajapatsasvaltuuskunnasta perinnesäätiöksi: Suomen Marsalkka Mannerheimin perinnesäätiön synty ja toiminta (Helsinki: Suomen Marsalkka Mannerheimin perinnesäätiö, 2005), 27.

${ }^{18}$ Tuomas Tepora, "Changing Perceptions of 1918: World War II and the Post-War Rise of the Left," in The Finnish Civil War 1918: History, Memory, Legacy, ed. by Tuomas Tepora \& Aapo Roselius (Leiden: Brill, 2014), 387-9.
} 
statue stood old railway storage buildings, unused tracks, and open space around Töölönlahti Bay. This part of the city has only experienced heavy development from the 1990s on. The construction of Kiasma, the Museum of Contemporary Art, began that development.

The original 1950s' public discussion of where to erect the statue would almost merit another chapter. Suffice it to say, however, that in line with the cultic characteristics connected with Mannerheim, there was a clear hierarchy in opinions regarding the best locations. The hierarchy was based on the social proximity of the debater to Mannerheim. Who, it might be asked, had the right and the power to express, or even have access to, an opinion that would echo the authentic feelings and opinions of the Marshal? And vice versa, who possessed enough status and credibility to satirize the location debate? ${ }^{19}$ This is important, because similar emotions and status fights for representation were also expressed in the early 1990s, when the Museum of Contemporary Art seemed to threaten the position of the statue. During the Cold War, the sides in the debates and satires were comprised of the far Left and the others. But in the early-1990s, it was difficult to pinpoint the sides politically. In general terms, the two sides to the controversy were the statue-defending "neopatriots" and the museum-defending "cosmopolitans." Unlike during the Cold War, neither side visibly tried to besmirch Mannerheim's legacy or make his imagery appear foolish. Both sides constructed Mannerheim images so as to argue for their positions in the debate.

The building project to house the contemporary collection of the National Gallery of Art began in the late 1980s. The state acquired a valuable site for the building from the city of Helsinki. The vast unbuilt land in the center of the capital city adjacent to the Mannerheim statue needed urban revitalization, but the site for the museum building was tight and closely bordered the site of the statue. Thus, relocation of the statue by $20 \mathrm{~m}$ was already on the agenda during the city planning discussions in 1991. In 1992, the city approached the Mannerheim Heritage Foundation about relocating the equestrian statue. The Foundation rejected even a modest move. By that time the veteran's movement had acquired great visibility and had earned public respect. The relocation of the statue without the consent of the Mannerheim Heritage Foundation would have left city officials in a dire, even a shameful, position. The legacy of the veterans found itself in the line of fire.

${ }^{19}$ Tepora (2017), 297-8. 
However, the same year a call for an architectural competition was announced and the city decided to grant the competitors the right to move the statue. The Foundation reacted, and in 1993 city manager Kari Rahkamo assured the board of the Foundation that the statue would remain untouched. ${ }^{20} \mathrm{Up}$ until then, the controversy had received very little public attention, but the structure of its future narrative had already been scripted. The relocation of the Mannerheim statue would violate the memory and the legacy of the veterans. Thus, it would undermine the collective experience of not only the "veterans' generation" but of the public patriotic sentiments that had recently gained prominence.

The American architect Steven Holl received first prize in the competition. His design, titled Chiasma (Kiasma), meaning an X-shaped configuration, annoyed lay people as well as many Finnish architects. For the laypeople the design seemed ugly, and for the professionals the building's location was misplaced. The first round of public outcry in 1993 concerned the design of the building and was mainly carried out by architects. In this debate, the location of the statue received next to no attention. According to the debaters, the major problem with the decision of the competition was to award the first prize to a foreigner. Society was suffering from a recession but the state and the capital city were about to carry out a major design and building project. Why not support local architecture and national design? As usual, local citizens also voiced their concern over the prospective building. Without voicing any particular interest in the fate of the Mannerheim statue, a society called Pro Töölönlahti Bay drew attention to its aim to save the undeveloped Töölönlahti Bay area from construction. Moreover, the postmodern design of the building felt alien to many people. ${ }^{21}$

The final and the most visible round of the Kiasma controversy began in the spring of 1994, when the city council prepared to make the final planning decision on the new museum building. This debate became the media spectacle of the year and made the juxtaposition of the Mannerheim statue and contemporary art a public question of loyalties. Either one sided with the veteran's movement, represented by the Mannerheim Heritage Foundation and the Mannerheim statue, or one chose contemporary art with its fluid, unrooted values and postmodern buildings (Fig. 14.1).

${ }^{20}$ MHF, Folder F 1: Letters (1980-1993), letter from Kari Rahkamo to the MHF, 3 August 1993.

${ }^{21}$ Helsingin Sanomat 14 March 1994. 


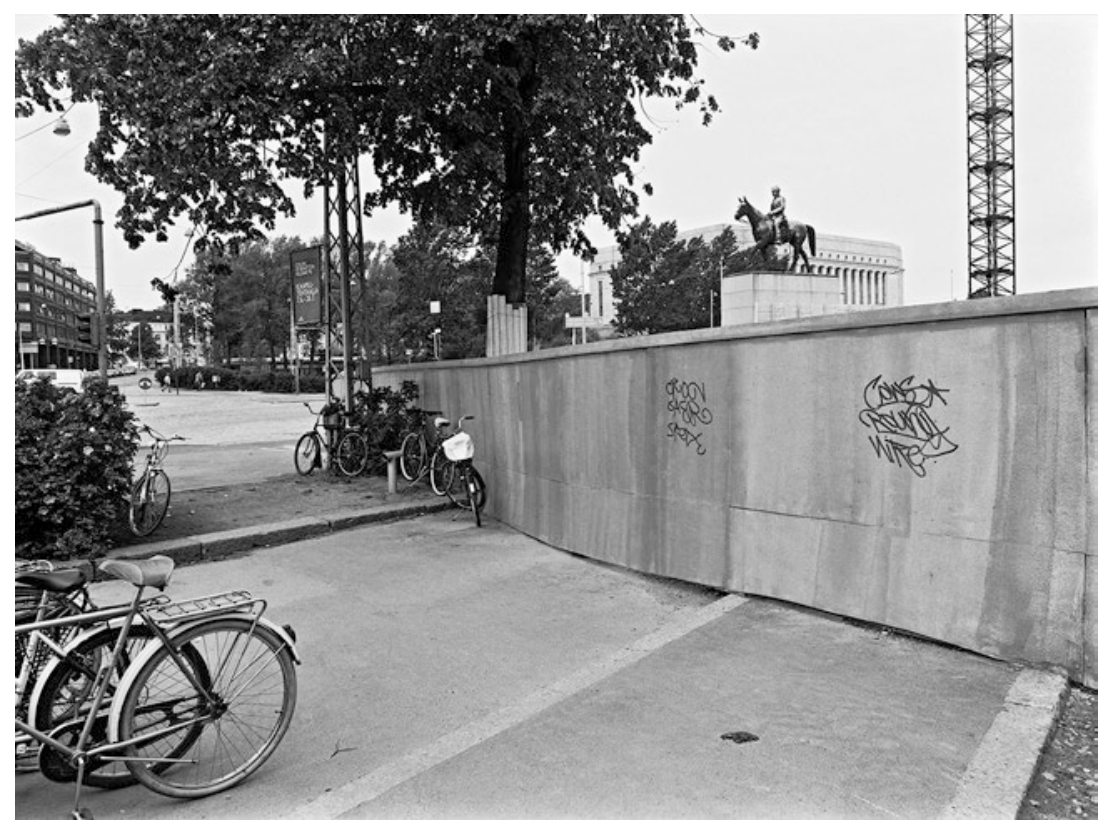

Fig. 14.1 The construction site of Kiasma, the Museum of Contemporary Art in Helsinki, 1996. (Photo: Jan Alanco, Helsinki City Museum)

\section{A Populist Momentum}

It can be said that in the early 1990s Finland experienced the formation of a third republic, following the first republic of the interwar period and the second republic of the Cold War era. Many people had to decide whether patriotism and the EU were compatible with each other. Many citizens seemed to experience the nation by being forced to scrutinize their collective attachments, identities, and hopes for the future. The answers were diverse, but some form of patriotism seemed to permeate many of the responses. Populist nationalism was one of the answers put forward. The Mannerheim statue in Helsinki thus became an emotional figure that defined the expectations and fears of social transformation of the society from an introverted and homogenous nation to a Europe-bound country. 
First, the problem concerned whether the Mannerheim statue should be moved slightly. This embodied realistic concern and a question. ${ }^{22}$ However, even in the beginning it seemed probable that the statue would remain on its present site. Surprisingly, the debate did not cool down. The next round of the debate concerned whether the statue was going to be relocated to an entirely new site. Finally, as spring progressed, the yellow press and op-eds in the Helsingin Sanomat, the nation's largest newspaper, discussed whether contemporary art and Mannerheim were compatible at all. Should the museum be built elsewhere? This media debate did not reflect realistic concerns of the city planners and politicians. It reflected a skillfully crafted campaign against the perceived contemporary rootlessness symbolized by contemporary art and the forgetting of the nation's wartime history. The yellow press in particular sensed the populist advantage to making headlines out of incomprehensible contemporary art contained within an ugly building abutting the Mannerheim statue.

Backed by the veterans' and reservists' organizations, the Mannerheim Heritage Foundation approached the members of the city council in late March with a letter requesting that the Marshal's statue be protected. Immediately afterward, the foundation held a press conference. Every major news medium was present. It could be said that Mannerheim rode again and lifted General Ehrnrooth onto fame. In mid-April, the foundation handed city manager Rahkamo and the members of the city government a petition signed by fourteen defense and other civil organizations, including the associations for war invalids and career officers. The signatories petitioned the city not to build the museum too close to the statue. Visibly led by Ehrnrooth, the foundation also decided to approach the government. The Museum of Contemporary Art was a state museum, and it petitioned Culture Minister Tytti Isohookana-Asunmaa and the Chief Secretary of the Ministry of Education, who had presided over the architectural competition. All of the petitions made headlines in the national media.

The sculptor of the Mannerheim statue, Aimo Tukiainen, supported the Mannerheim enthusiasts. He saw the area surrounding the statue as belonging to the concept. The Marshal's statue required open space. Tukiainen's legal petition to preserve the environs of his artwork did not succeed although Tukiainen did not oppose the museum but only its location. ${ }^{23}$ This aspect resonated with the public. In an opinion poll conducted

\footnotetext{
${ }^{22}$ Helsingin Sanomat 1 September 1993.

${ }^{23}$ Helsingin Sanomat 30 June 1994.
} 
among the visitors to the National Gallery in October 1994, the most often-cited reason for opposing the building of the museum on its designated site was felt to be the badly chosen location. Mannerheim and contemporary architecture caused some people symptoms of cognitive dissonance. However, this opinion poll among the art lovers showed that a clear majority did not see a problem with the location of the museum. ${ }^{24}$

The MHF understood to appeal to the negative feelings contemporary architecture and art induced in some segments of the public. In media discourse, Mannerheim became a symbol of popular taste and the will of the people. Why, some wondered, cannot the citizens decide if the museum is compatible with the Mannerheim statue? And was this question not like the upcoming EU referendum? The general public was the best expert, wrote one Helsinki-dweller in an op-ed. The elites and experts despised public opinion. ${ }^{25}$ The provinces rose up, and contemporary art received even less understanding outside the capital. Some local people published satirical op-eds that suggested the relocation of the statue outside of Helsinki. ${ }^{26}$ "Marski is the affair of all of Finland," wrote a man from Jyväskylä in Central Finland, using the diminutive of "Marshal." Helsinki's choice for the location of the museum sprang from the bad taste characteristic of the people in the capital. They did not have the moral right to destroy the nationally precious environment. The junk of contemporary art threatened to "drown" the statue, which was supposed to remind future generations that Finland is "worth defending." 27 General Ehrnrooth made the last line famous and omnipresent.

In the early 1990s, as nationalism gained support and the public duly showed respect for the work of the war generation, the supporters of the neo-patriotic causes experienced constant threats and potential profanation of sacred values. The battle was by no means waged between the capital and the rest of Finland. Many citizens of Helsinki reacted angrily against the new museum building. Opponents belonged to various social classes and language groups. For instance, a Swedish-speaking veteran with an aristocratic background published an op-ed in which he lamented how the Marshal was on his way to becoming a gatekeeper for a museum, a porter in the street: "Shame," he wrote, "on you who have the power." 28

\footnotetext{
${ }^{24}$ Helsingin Sanomat 13 October 1994.

${ }^{25}$ Helsingin Sanomat 3 June 1994.

${ }^{26}$ See, for instance, Helsingin Sanomat 26 May 1994.

${ }^{27}$ Helsingin Sanomat 24 May 1994.

${ }^{28}$ Hufvudstadsbladet 25 May 1994.
} 
Another Swedish-speaker could not understand the need for a museum to be built in the midst of a dire economic situation. It was "sad" that the Marshal had been drawn into "this inconceivable case." 29 Many of the residents of metropolitan Helsinki were as disappointed with the city planning officials and the "elites" as their fellow citizens in other parts of the country. ${ }^{30}$

As the decisive meeting of the city council approached, the stakes climbed higher. Ehrnrooth had already become a "monument" himself, as a prominent Finnish author characterized the 89 -year-old general. ${ }^{31}$ It was his moment to step up and publish an open letter in a number of newspapers. In undertaking this task, Ehrnrooth decided to write as a private citizen. He presented himself as the authority on Mannerheim's legacy and the intermediary of his will, as a kind of incarnation. He refused to take for granted that city manager Rahkamo had promised to leave the statue intact. He enlightened him: "Do you know history, city manager Rahkamo?" If not, Ehrnrooth was ready to lecture: "Independent Finland would not exist without Mannerheim." Old and already feeble Ehrnrooth possessed charisma that appealed to large segments of the citizens, not only the war generation but also the young. He used his old age to teach the "young" city officials. He reminded them that the statue had been funded by public fund-raising. The bureaucrats did not have the right to destroy the will of the people and their possession. "One who does not know the history of one's country, does not control the present and thus cannot plan the future." 32 The Museum of Contemporary Art adjacent to the statue of the most important personality in the history of the nation represented plain ahistoricity, a crime against sacred Finnish values. Citizens encouraged by Ehrnrooth, aided by the scandal-hungry yellow press, pointed their fingers at Helsinki-based elites, the perceived rootless and unpatriotic people. ${ }^{33}$ At this time, it became clear that the MHF and the public who stood up for the popular Mannerheim image opposed the construction of the museum altogether. The battle was not about the new museum but between two worldviews that represented distinct moralities.

In many ways the campaign to protect the Mannerheim statue was also the personal project of Adolf Ehrnrooth (1905-2004), who silenced

\footnotetext{
${ }^{29}$ Hufvudstadsbladet 25 May 1994.

${ }^{30}$ See, for instance, Helsingin Sanomat 21 May 1994 and 9 June 1994.

${ }^{31}$ Helsingin Sanomat 27 March 1994. Jukka Kemppinen on Ehrnrooth's memoir.

${ }^{32}$ Helsingin Sanomat 14 May 1994. The letter was sent to 110 media.

${ }^{33}$ See, for instance, Hotline poll results in Ilta-Sanomat 7 May 1994.
} 
differing opinions even within the MHF. ${ }^{34}$ Before the 1990s, he had been known for his work for the veterans' organizations and as a decorated frontline commander in World War II. He had become a vocal and distinguished mouthpiece for the veterans' organizations in the 1980s but was not generally known to the public. The year 1994 therefore became his year. His memoir published early the same year, entitled Kenraalin testamentti (The Will of the General), ${ }^{35}$ topped the non-fiction charts and established him as a "Vice-Marshal." The book assured readers that Finland was, 50 years earlier just as today, worth defending. The aristocrat with the Danish spouse claimed, among other obscure one-liners, that multinational states were doomed to fail and that Finland was the best country for the Finns.

Next, Ehrnrooth and the MHF petitioned newly elected President Martti Ahtisaari and the government not to build the museum too close to the statue. President Ahtisaari responded that he was not in a position to get involved in the ongoing civic debate. ${ }^{36} \mathrm{He}$ responded, however, by giving the veterans' organizations a visible and celebratory place in the Independence Day celebrations scheduled for later in the year.

The MHF did not give in. Only a few days before the first city council meeting regarding the urban planning of the museum site, a young attorney approached the MHF and proposed that the foundation suggest that the city hold a referendum on the matter. According to municipal law, if two percent of the citizens with the right to vote signed a petition to act on a perceived defect, the municipal council was compelled to formally consider the complaint. Hurriedly, the board of the MHF set up an organization to gather signatures from the public. The organization consisted of active members of the union for reserve and noncommissioned officers, with members of voluntary defense organizations added. Within four days, these enthusiasts were able to more than double the needed number of signatures. In the end, more than 23,000 Helsinki citizens signed the petition. ${ }^{37}$

Ehrnrooth handed the petition to the deputy city manager on 3rd June. The following day marked the 127th birthday of Mannerheim, while

${ }^{34}$ E-mail interview with Matti Klinge 27 November 2017.

${ }^{35}$ Adolf Ehrnrooth and Marja-Liisa Lehtonen, Kenraalin testamentti (Helsinki: WSOY, 1994).

${ }^{36}$ Tepora (2017), 309.

${ }^{37}$ MHF, Folder Hb 1: Minutes of the Board (1980-2000), memorandum 1994: publicity campaign for the protection of the Mannerheim equestrian statue. 
4th June had also been the date of the Flag Day of the Defense Forces since 1942. The MHF board and about 300, mainly older, enthusiasts gathered at the statue to pay their annual respects. At that moment, the participants staged the last melodramatic event undertaken to save the memory of "the greatest of the sons of our time." In the press, Ehrnrooth even appealed to God to protect the statue. ${ }^{38}$ "National pride is not the same as chauvinism," he told the audience. He also evoked historical parallels from the interwar period when the "chauvinist" segments of society had threatened to remove, and had desecrated, statues and memorials in the capital dedicated to Russian sovereigns. The public, according to the General, had risen to protect them. Today it seemed as if these Russian figures that evoked mixed emotional memories were more important than the Marshal of Finland. ${ }^{39}$

The city government did not agree with the public on the need for a referendum, and eventually the city council decided against it by an overwhelming majority. It was felt that urban planning should not be decided by a general vote. The Green League Council member Kalle Könkkölä crystallized the fear many politicians had of the populist will of the perceived silent masses: "Contemporary art would lose in a referendum."

The Council member was right. Because of the massive effort of the MHF to stop the construction of the museum, we are today able to follow the nationwide opinion-poll statistics surrounding the statue saga. In the early June of 1994, the MHF commissioned from a major opinion poll company a poll of the attitudes toward the museum and statue debate. One of the rather prescriptive questions read: "Should Parliament/ Government have an effect on the protection of the [Mannerheim] equestrian statue that has been created by funds collected from the public?" Fifty-nine percent of all the respondents answered yes, twenty six percent voted no, and fourteen percent remained undecided. There was no marked difference in opinions between genders. Occupation-wise the protection of the statue interested primarily the working classes and the pensioners. No indication of socialist ideology surfaced here. When classified by place of residence, the protection of the statue received more support in the countryside and in small towns than in larger urban areas. The difference in support between generations is perhaps the most interesting result. The

\footnotetext{
${ }^{38}$ Hufvudstadsbladet 7 June 1994.

${ }^{39}$ Helsingin Sanomat 5 June 1994.

${ }^{40}$ Helsingin Sanomat 16 June 1994.
} 
older generations supported the statue, but so did the youngest. In the age group of 15-29, 61 percent favored "protection" of the statue and only 29 percent were against it. According to later research, neo-patriotism affected the generation that came of age in the 1990s by molding their attitudes toward a more conservative stance than that of their parents, the baby-boomers. ${ }^{41}$ As a matter of fact, in the age group of 30-49, the cause of the statue protectors received the least support, yet formed the majority. ${ }^{42}$ The representatives of the older segments of this age group had come of age during the heat of the Cold War and had a more restrained attitude toward open celebration of conservative nationalism than the younger generation, whose formative transnational experiences had included the fall of the Berlin Wall and the end of the Soviet Union.

\section{“The EQUESTRIAN STATUE OF MODERNISM"}

The museum and statue debate would not have been a proper debate unless the supporters of the new museum building and contemporary art had not participated in it. Columnist Tuomas Nevanlinna observed in June 1994 how the sides of the debate did not genuinely try to overcome their differences of opinion. The protectors of the statue believed that the sacred values of independence and of the veterans were being offended. Equally, the supporters of the museum were strong in their own belief. They treated the project as if they were erecting the "equestrian statue of modernism." ${ }^{43}$ Nevanlinna's phrase implied that Kiasma represented a new monument for a new era.

The wall between the debaters was not impenetrable, at least not from the museum side. For the recoding of Mannerheim, the rhetoric of the museum directors turned out to be most fruitful. The Mannerheim image did not conform to a single populist and conservative mold. Tuula Arkio, the director of the Museum of Contemporary Art, employed the

\footnotetext{
${ }^{41}$ Ahonen (1998), 74-89; Tuomas Tepora, “Toisen maailmansodan muistokulttuuri: Kommunikatiivisesta muistamisesta kulttuuriseen muistiin," in Puolustuslinjalla: Yhteiskuntatieteellistä ja historiallista tutkimusta maanpuolustuksesta ja asevelvollisuudesta, ed. by Teemu Tallberg, Anni Ojajärvi \& Tiia Laukkanen (Helsinki: Nuorisotutkimusverkosto, 2017), 127-8; Aamulehti 8 June 1994.

${ }^{42}$ MHF, Folder F 2: letters (1994-2000), poll commission for Taloustutkimus, 1 June 1994; Foundation for the Mannerheim Cross Knights archives (MCK), letters 1991-1995, Taloustutkimus poll results: The protection of the Mannerheim equestrian statue, 1994.

${ }^{43}$ Rakentaja 8 June 1994.
} 
great-man image of Mannerheim in support of contemporary art. In an op-ed response to Ehrnrooth, Arkio illustrated how the petition against the museum had proved that the MHF and the supporters of its cause did not aim at the protection of a work of art, the statue. Instead, they were attacking contemporary art, which they did not consider worthy of Mannerheim. Contemporary culture and independence seemed incompatible. Had Mannerheim led in battle only in order for Finnish culture to lose its vitality? "Mannerheim was a cosmopolitan who was genuinely interested in other cultures," she wrote, adding that he had been a "scientist" of other cultures. "If [the MHF] does not have the courage to face contemporary culture and values, it testifies cowardice in hiding behind the back of Mannerheim. It basically feels that Mannerheim is being desecrated while not being able to defend himself." As a climax, Arkio asked whether Mannerheim had left Finland for good, as he did after his presidency, because of the intellectual climate in the country. ${ }^{44}$

Arkio was backed by other higher state officials active in art and culture administration. For instance, the director of the state visual art committee contributed to the self-flagellation of "immature national consciousness" led by "random emotions." 45 Architect Steven Holl had initially been unaware of Mannerheim's significance in Finland. By now, however, he had done his homework. He expressed publicly that Mannerheim had been a "true person of culture," who would have wanted to have the museum next to his statue. ${ }^{46}$ What linked the debaters across the divides was the importance they invested in deciphering the "true" attitudes and feelings of Mannerheim.

Ehrnrooth's campaign to woo the general public also overshadowed differing voices close to the MHF. University of Helsinki history professor Matti Klinge had served on the board of the foundation just prior to the escalation of the statue imbroglio. According to Klinge, General Ehrnrooth had fired him from the board after the professor had expressed a conciliatory opinion regarding the proposed relocation of the statue by a few meters. ${ }^{47}$ Later Klinge participated in the debate by voicing concern over how the media and the public opinion had suddenly transformed the meanings of Mannerheim and "culture" into the opposites of one

${ }^{44}$ Helsingin Sanomat 30 May 1994.

${ }^{45}$ Ilta-Sanomat 2 June 1994.

${ }^{46}$ Ilta-Sanomat 1 June 1994.

${ }^{47}$ Matti Klinge e-mail interview (2017). 
another. ${ }^{48}$ For the professor, Mannerheim did not represent a folk character but, rather, an ancien régime role model for the people to look up to. ${ }^{49}$

Unavoidably, the debate generated satirical commentary and criticism of "great-man" narratives and idolatry that nevertheless contributed to the publicity and modern myth surrounding the Marshal. Journalist and author Jari Tervo suggested that it would be best to remove all the buildings within a radius of $10 \mathrm{~km}$ of the "center of our universe, the Mannerheim statue." The Museum of Contemporary Art would be best located on "some outlying islet" off the coast of the city. Art critic Markku Valkonen captured in his satire the significance of Mannerheim perhaps the most incisively. As he saw it, the spirit of Mannerheim resided in the statue. Both sides in the debate sought guidance and permission from this spirit. What would have Mannerheim himself wanted? The statue itself as a work of art was not important, nor was the museum. The real concern was whether the powerful spirit of the leader had been offended. What if the great warrior-chief's rest had been interrupted? That would constitute an offense against the tribal immanence of Finland. Did the debaters possess enough mana to ward off the revenge of the great forefather? ${ }^{50}$

The cultural elite refashioned Mannerheim into a cultural hero who was a cosmopolitan in a narrow-minded nation. They usually criticized any personality cult stemming from a popular, if not vulgar, desire. In other words, their Mannerheim image resembled their own mirror-image, that of being above the common people.

\section{Moral Panic}

It is now clear that the 1994 statue and museum debate did not concern first and foremost either the Mannerheim statue or the Museum of Contemporary Art. It represented a moral panic caused by social changes and uncertain expectations about the future. By that I mean a mediatized and viral belief that addressed the moral foundations of the society. The "eternal change" symbolized by contemporary art threatened the moral basis of the nation. The everyday means of emotional navigation had

${ }^{48}$ Hufvudstadsbladet 1 June 1994.

${ }^{49}$ Matti Klinge, "Myytti," in Mannerheim: Sotilas ja ibminen, ed. by Kari J. Sillanpää \& Harri Westermarck (Helsinki: Yliopistopaino, 1992).

${ }^{50}$ Helsingin Sanomat 29 May 1994. 
failed. Some segments in the society observed disturbances, not perhaps so much from their own moral compass but from the compass of others. The work of the war generation seemed redundant in the face of conceding independence to the EU and having postmodern architecture cast a shadow over the national-conservative image of the Marshal.

General Ehrnrooth captured the statue discourse in one perception: contemporary art and the Mannerheim statue did not fit together. They represented two distinct worldviews. ${ }^{51}$ This crystallized what moral panic meant. "The eternal values of the fatherland" were in danger of being sacrificed to the "ever-changing values of the present," he asserted.

Modern, media-driven moral panics need not capture the entire society. Nor did the Mannerheim statue debate. It was a symbol, or a symptom, of the anxieties that accompanied social change. Another concurrent and more visible moral panic concerned fear of satanic-ritual abuse. This media-driven panic began in North America in the late 1980s. The satanic panic began with reported cases of ritual child abuse, and by the early 1990s it had become a cultural phenomenon in Western Europe and the Nordic countries. Little or no evidence for cult-based abuse was ever produced, but Satanism as an infamous subculture captured public attention. In the Finnish context, scholars have connected the satanic panic with the social changes of the 1990s, although the epidemic was actually a transnational scare. ${ }^{52}$ The collapse of the Soviet Union affected religious sentiments and values. The eastern superpower had represented an institutionalized evil. Its disappearance and the relative weakness of the new Russia contributed to the spiritual search for an alternative evil, something that was especially true among the religious section of society.

What did Mannerheim have to do with the fear of an adolescent plagued by the devil? Seemingly not much, but contemporary art on the other hand did, and so did the overall atmosphere that contributed to uncertainty about the future. In the early 1990s' atmosphere, art historian Jaakko Puokka published a yellow-press op-ed, in which he asked if the new Museum of Contemporary Art was a "temple for Satan." This piece may not have been entirely serious in its spiritual connotations, but it was not meant as satire either. It made clear how deeply "satanic" architecture

${ }^{51}$ Helsingin Sanomat 26 May 1994.

${ }^{52}$ Titus Hjelm, Saatananpalvonta, media ja suomalainen ybteiskunta (Helsinki: Yliopistopaino, 2005), 189-211. 
violated urban space and harmony. Citing Biblical sources, the author compared the form and details of "Chiasma" to Old-Testament Leviathan, the king of all beasts and a lethal serpent, the creature of chaos that brings the end of the world. ${ }^{53}$

\section{Conclusion: Mannerheim Recoded}

In this chapter, I have described the Mannerheim images of the early 1990s as emotional figures. Public opinion, the media and interest groups, notably the Mannerheim Heritage Foundation, refashioned preexisting emotional Mannerheim figures to contain the new challenges created by an altered foreign policy, a deep recession, the joining of the EU and cultural struggles connected with neo-patriotism.

For the participants, the Mannerheim statue debate of 1994 held moral consequences. The implications were portrayed as defining the destiny of the nation, a nation that had metaphorically recently escaped from the restraints of the Soviet Union, was experiencing a dire recession and was about to join the European Union. The debate pitted the heritage of the war generation and the "eternal values of the nation" against the values of "the ever-changing and elusive, rootless present." The Mannerheim Heritage Foundation, led by General Adolf Ehrnrooth, initiated the battle aimed first at blocking the Mannerheim statue from being removed from the path of the new museum building for contemporary art. Subsequently, the battle inflated to preventing the construction of the museum altogether. The battle waged by the MHF ended in defeat, but emblematically the supporters of the heritage foundation saw their fight as a "defensive battle" echoing the neo-patriotic overtones of the decade. ${ }^{54}$ Mannerheim, however, did not lose the battle. The supporters of the museum evoked an image of an art-loving cosmopolitan who would have loved to see a worldclass museum housed in a modern building located beside his statue.

Emblematic, transnational phenomena of the turn of the 1980s and 1990s were moral panics, meaning widely shared and media-driven experiences of threat to societal security and the future. While reasons behind the panics were manifold, especially in Finland and in the context of the end of the Cold War, the political, social, and economic changes of the early 1990s became associated with the feelings of insecurity. These

\footnotetext{
${ }^{53}$ Iltalehti 20 June 1994.

${ }^{54}$ For example: MHF, folder F 2: letters (1994-2000), private letter to Adolf Ehrnrooth, Helsinki 1 May 1994.
} 
feelings were expressed in the panics that varied from satanic-ritual abuse to the fear of immigration and that gender roles were in jeopardy. ${ }^{55}$

In this context, the supporters of conservative Mannerheim images refashioned their idol into a protector of the nation from the perceived rootlessness and ahistoricity of the post-Cold War society. Interestingly, however, the proponents of liberal and cosmopolitan values also harnessed Mannerheim in their fight against the perceived restraining forces that seemed to prevent Finnish society from renewing itself. It is thus not surprising that the decade that has since been named the "neo-patriotic" decade experienced an extensive search for guidance from the image of its dead leader.

It is important to understand that the perceived legacy of the veterans was a historical variable. The strong populist support for the leaders of the veterans' organizations could not have occurred during the Cold War or even in the late-1980s. It is also difficult to imagine such strong popular and populist indignation caused by perceived formless and rootless contemporary art ten years later in early millennial Finland.

The MHF continued its battle till the end. It filed a complaint on the urban area development plan first with the Ministry of the Environment and then with the Supreme Administrative Court, together with, among others, sculptor Aimo Tukiainen and the Pro Töölönlahti Bay society. The Court dismissed the complaint in $1995 .{ }^{56}$ However, the polemic regarding the suitability of the museum to its construction site continued until the inauguration of the new museum in 1998. Final public indignation arose concerning the color of the fence circling both the construction site and the Mannerheim statue. An art student won the competition to paint the fence and chose to do it in magenta. Since the press reported that as the color pink, the outcry was immediate. Mannerheim with his horse in a pink stall! The side of the fence that ran sideways to the statue, and facing Mannerheim Road, was quickly repainted gray. ${ }^{57}$

\footnotetext{
${ }^{55}$ For a contemporaneous analysis, see Juha Siltala, Miehen kunnia: Modernin miehen taistelu häpeää vastaan (Helsinki: Otava, 1994), 10-14.

${ }^{56} \mathrm{MHF}$, Folder Hb 1: Minutes of the Board (1980-2000), judgment of the Supreme Administrative Court, 11 November 1995.

${ }^{57}$ Hufoudstadsbladet 16 April \& 10 May 1996; Helsingin Sanomat 25 April, 3 May \& 11 May 1996; Iltalehti 16 April 1996; Ilta-Sanomat 8 May \& 11 May 1996.
} 
Open Access This chapter is licensed under the terms of the Creative Commons Attribution 4.0 International License (http://creativecommons.org/licenses/ by $/ 4.0 /$ ), which permits use, sharing, adaptation, distribution and reproduction in any medium or format, as long as you give appropriate credit to the original author(s) and the source, provide a link to the Creative Commons licence and indicate if changes were made.

The images or other third party material in this chapter are included in the chapter's Creative Commons licence, unless indicated otherwise in a credit line to the material. If material is not included in the chapter's Creative Commons licence and your intended use is not permitted by statutory regulation or exceeds the permitted use, you will need to obtain permission directly from the copyright holder.

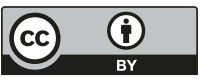

